\title{
Determinants of Digital Taxation in European Union
}

\author{
MARIO HAK \\ Tax office \\ Ministry of finance \\ Županijska 14, 34000 Požega \\ REPUBLIC OF CROATIA \\ ANTON DEVČIĆ \\ Department of Social Sciences \\ Polytechnic of Požega \\ Vukovarska 17, 34000 Požega \\ REPUBLIC OF CROATIA \\ HRVOJE BUDIĆ \\ Department of Social Sciences \\ Polytechnic of Požega \\ Vukovarska 17, 34000 Požega \\ REPUBLIC OF CROATIA
}

\begin{abstract}
The article analyzes the introduction of digital taxation on the member states of the European Union. The digital economy is a collective term for all economic transactions that take place

happening on the Internet. It is also known as the Web economy or the Internet economy. With the advent of technology and the process of globalization digital and traditional economies merge into one. New ways of doing business in the virtual and digital world economy caused the emergence of a tax on digital services (hereinafter: digital tax). A solution is being sought internationally and globally, which is certainly a better and more systematic approach, however in this text we will see that states have decided to introduce a digital tax on their own
\end{abstract}

Key-Words: digital taxation, digital economy, virtual and digital world, corporate taxation

Received: April 23, 2021. Revised: October 7, 2021. Accepted: October 22, 2021. Published: November 2, 2021.

\section{Introduction}

The global economy is rapidly becoming digital and, as a result, new ways of doing business have emerged. Digital companies are characterized by the fact that their operations are strongly linked to the internet. In particular, digital business models rely to a large extent on the ability to conduct activities remotely and with limited or no physical presence, on the contribution of end-users to value creation, and on the importance of intangible assets.

The current corporate taxation rules were mainly developed during the 20th century for traditional businesses. They are based on the idea that taxation should take place where value is created. However, the application of the current rules to the digital economy has led to a misalignment between the place where profits are taxed and the place where value is created, notably in the case of business models heavily reliant on user participation. It has therefore become evident that the current corporate tax rules for taxing the profits of the digital economy are inadequate and need to be reviewed. That review constitutes an important element of the given that the digital single market needs a modern and stable tax framework for the digital economy to stimulate innovation, tackle market fragmentation and allow all players to tap into the new market dynamics under fair and balanced conditions.

\section{Method of research of introducing digital taxation}

The starting point is data and forecasts published by Statista on revenue in different digital markets. [10] Statista classifies the digital market into 8 main categories (e-services, e-commerce, digital media, digital advertising, e-travel, connected car, e-health, smart home), which are further broken down in subcategories. Cloud computing is covered separately. For e-payment there has been no reliable 
data on revenues earned in the sector (only on transaction volumes). Note that e-commerce, connected car, e-health, and smart home all relate to applications for physical goods and are not within the scope of this exercise. The table below shows how these categories relate to the business models used in this impact assessment. As reference year, Statista forecasts for 2019 were used. All estimates are static, that is they do not take into account any behavioural responses.

It is important to determine whether the tax issues related to the digital economy could be sufficiently tackled by the implementation and rigid execution of anti-tax avoidance regulations, inter alia transfer pricing rules. [6] The digitalisation of the global economy is happening fast and permeates almost all areas of society. Although the size of the 'digital economy' is still relatively small - estimates revolve around $4-5 \%$ of value added - businesses of all kinds now derive much of their value from intangible assets, information and data. As a result, the digital economy displays a very strong growth path. Close to a third of the growth of Europe's overall industrial output is already due to the uptake of digital technologies. (Vandermerwe, S. and Rada, J. p. 18). Between 2006 and 2016, digital advertising revenue in Europe has multiplied by more than 5. Among other things, (digital) taxes should be designed such that companies can easily determine which tax burden will apply if they provide services in a particular country. (Zöchling, Plott, Rosar, \& Dziurdź, p. 1-19) [3]

There is no well-defined digital sector as such. Notably, the Information and Communication Technology (ICT) sector is no synonym for the digital economy. Digital companies should not be considered pre-dominantly as ICT companies. Many companies commonly considered as digital companies do not belong to the ICT sector. The 2017 World Investment Report [8] has developed a methodology to classify international companies into (1) digital companies, (2) IT and telecoms companies (both enablers of the global digital economy) and (3) 'other multinational companies'. IT and telecoms companies are broadly equivalent to the ICT sector. They are either IT hardware manufacturers or software developers/providers of IT services, or they are providers of telecommunication infrastructure and connectivity. Digital companies are characterised by the nature of their operations, which are strongly linked to the internet. The report further distinguishes between providers of internet platforms, e-commerce, digital solutions and digital content. European companies may forfeit competitiveness by losing ground to competitors from other countries and continents. [1]

Focussing on the top companies in each category clearly shows the much more dynamic revenue growth in the digital sector. Based on a unique assignment of companies into one of the categories, UNCTAD [9] has produced new lists of top 100 multinationals in the categories 'IT and telecoms' and 'digital'. Table (1) reports summary statistics for the largest companies in each category. Average revenue growth was around $14 \%$ for the top digital firms, compared to around 3\% for IT and telecom enterprises and $0.2 \%$ for other multinational enterprises, although total revenue by the largest digital companies is still considerably lower than that of the other sectors. The table also reports the 'international footprint' and the relevance of intangible assets, discussed in the next subsection.

Table 1 Revenue growth, international footprint and relevance of intangible assets of largest multinational companies (Based on UNCTAD (2017a and 2017b) and Bureau van Dijk Orbis database, Total revenue for the latest available year for the top companies in each category in $\$$ billion. 'Digital' and 'IT\&Telecoms' each consist of 100 companies. The category 'Other' only includes 83 companies, since some of the companies on UNCTAD's usual list of top 100 global companies belong to the first two categories. Annual average growth is measured over the latest 7 available years. International footprint is the ratio of the share of foreign sales in total sales to the share of foreign assets in total assets. The relevance of intangible assets is computed as the market capitalisation over equity book value minus 1 )

\begin{tabular}{|c|c|c|c|c|}
\hline $\begin{array}{l}\text { Type of } \\
\text { MNE }\end{array}$ & $\begin{array}{c}\text { Total } \\
\text { revenue }\end{array}$ & $\begin{array}{l}\text { Annual } \\
\text { revenue } \\
\text { growth }\end{array}$ & $\begin{array}{c}\text { Internatio } \\
\text { nal } \\
\text { footprint }\end{array}$ & $\begin{array}{c}\text { Relevance of } \\
\text { intangible } \\
\text { assets }\end{array}$ \\
\hline Digital & 872 & $14.2 \%$ & 2.1 & 3.1 \\
\hline $\begin{array}{c}\text { IT\&Tel } \\
\text { ecoms }\end{array}$ & 2825 & $3.1 \%$ & 2.2 & 1.2 \\
\hline Other & 5682 & $0.2 \%$ & 1.1 & 1.4 \\
\hline
\end{tabular}

Doing so for the three categories of largest global companies shows that, compared to the traditional non-IT companies, digital companies, have a much larger share of sales earned outside their home country relative to the assets they hold abroad. 


\section{Specificities of digital business models in relation to taxation}

The main characteristics of digital business models as compared to more traditional ones - are their ability to conduct activities remotely, the contribution of internet users in their value creation, the importance of intangible assets and a tendency to winner-takes-most dynamics.

Businesses in the digital economy can easily conduct activity remotely and are therefore very active in cross-border trade. Little physical presence is required to sell into a market. From one click on the computer, consumers can order goods and services from all over the world, translating into new market reach. For digital services more specifically, this is even more acute as the delivery of the service itself requires no or little physical presence. Such activities used to be mostly conducted locally in the destination location, and are now more and more conducted remotely in the country of origin (at source), although increasingly relying on consumer information from the destination country. As a result, businesses of the digital economy have a fundamentally different international footprint, with far fewer assets in the location of their foreign sales. One way to measure this phenomenon is by measuring the share of foreign assets in total assets against the share of foreign sales in total sales. The relevance of user contributions is central, materialising through the mass of adopters, the provision of personal data and other forms of user contributions to the production process. Participating in a platform or a network creates a value. As opposed to the conventional 'value chain' business model where value is generated by the supplier of a product or a service, a large part of the value derived by users of an online platform is created by other users.

\section{Type and level of digital activties}

Activities involving the supply of physical goods are relatively less problematic and have been dealt with to a larger degree through anti-abuse rules. First, these activities tend to have a balanced international footprint as they often require local physical (see Figure 2). Second, relatively more progress has been made within the OECD Base Erosion and Profit Shifting project in addressing issues in this area, notably through the measures that make the permanent establishment rules robust against commissionaire arrangements. Note that excluding the supply of physical goods does not mean that platforms charging fees for facilitating the trade of physical goods would be excluded. These platforms charge fees for a digital service. It means, however, that the underlying sale of the physical good would not be within the scope.

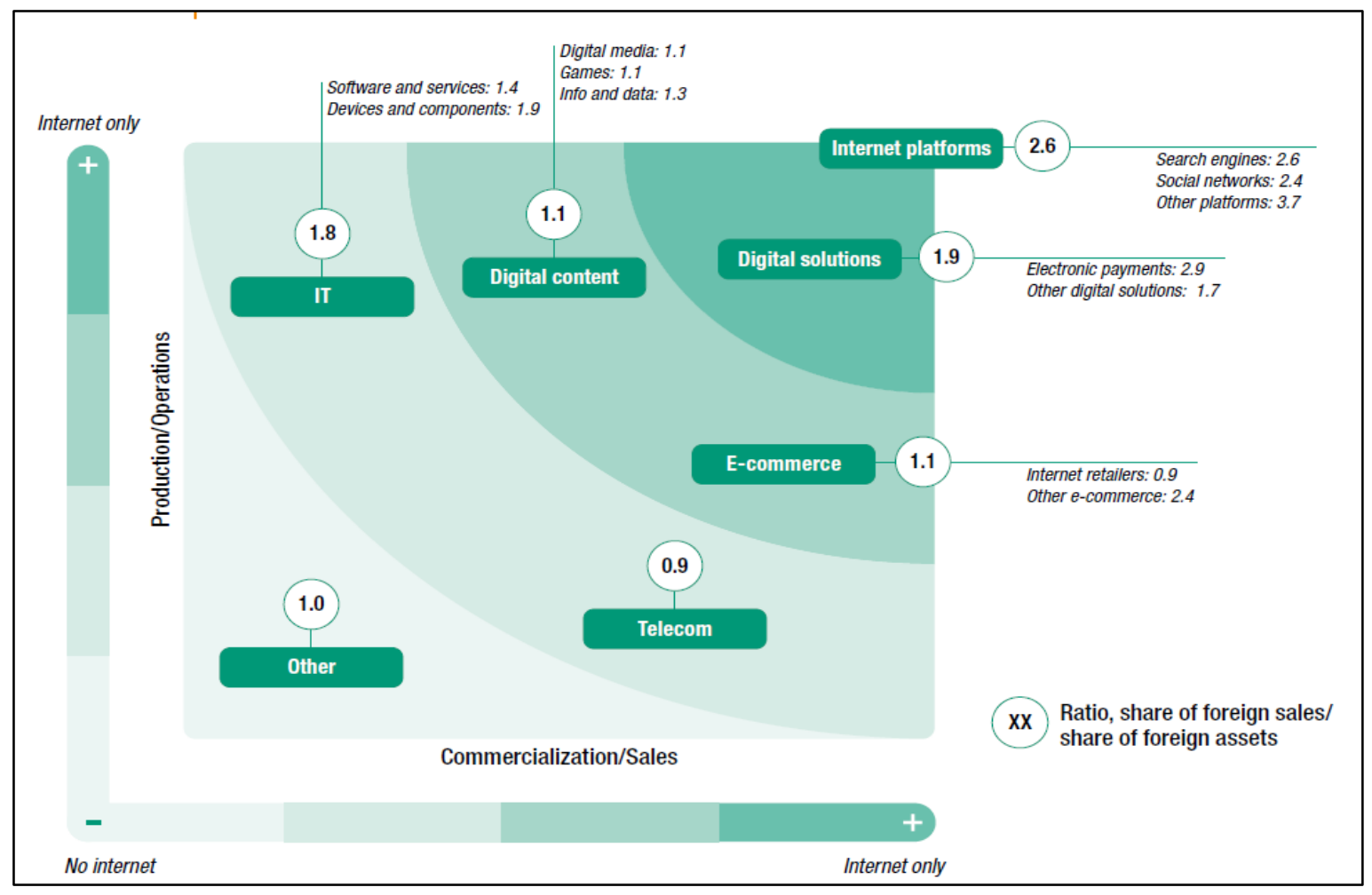

Figure 1 The internet intensity matrix and the foreign sales/assets ratio [7] 
Most of these remote activities by large global companies are conducted from non-EU locations. Only $50 \%$ of the affiliates of digital multinational enterprises are foreign-based, indicating the reduced need to be physically present abroad - for other (traditional) multinationals the share is $80 \%$. Large digital multinationals are particularly concentrated in the United States. From the top 100 digital multinational enterprises, two-thirds had their headquarters in the United States, whereas for tech companies and other multinationals the share was only $20 \%$. (UNCTAD, 2017a)

The comprehensive solution should not ringfence the digital economy but directly address its novel characteristics through a holistic approach that does not require singling out certain activities. The new rules should proportionately address the current mismatch between taxation and value creation. To the extent that the comprehensive solution can accommodate in its profit allocation rules the different degrees of contribution of digital factors to the process of value creation, the scope for the comprehensive solution can be defined broadly to include all digital services. A definition of digital services for the purposes of a revenue threshold could be inspired by the definition of electronically supplied services, which exists for VAT purposes. [11] This would entail covering a broad range of digital services.

Ideally the digital activity thresholds should be defined in a way to

a) Cater for different type of business models Digital business models are very heterogeneous. Some might rely on online contracts, while others do not. Some might have a very large user base while others might have a smaller user base, but still have significant user contributions as each individual user contributes a large value (users that produce content like videos or computer programs);

b) Ensure that trivial cases are not covered and that the compliance cost for dealing with an additional permanent establishment is safely covered by the profits generated through the permanent establishment. This is important for the proportionality of the proposed measure; and

c) Ensure a comparable treatment in different Member States, irrespective of their size.

A number of different types of activity thresholds have been proposed. [5] The thresholds most often discussed relate to:
Revenue earned from customers/users in the jurisdiction

$>$ Number of users (based on a concept of 'monthly average users'): A user is defined as any individual or business that registers, $\operatorname{logs}$ on or visits a company's digital platform.

$>$ Number of online contracts (agreements to terms of service): Online contracts are defined as legally binding agreements concluded by accepting (through 'clicks') the 'terms of service' of the digital service provider. [2]

The OECD (2015b) envisage to apply the revenue threshold in combination with other thresholds, but this option does not deal effectively with business models that operate through indirect revenue generation. Proportionality is a strong rationale for the application of a revenue threshold. However, the advantage of an alternative application of all thresholds is that it also deals effectively with respect to the advertising business model that generates revenue not directly from its users but indirectly through sales to third parties.

To ensure proportionality of the measure while operating alternative thresholds, it is essential to set each threshold sufficiently high to safely exclude small cases that would not even cover the tax compliance cost for a permanent establishment. Brauner and Pistone propose to make the thresholds flexible for countries to account for significant differences between countries, their geographical dimensions, the size of their economies, the number of inhabitants and other persons legally established on their territory, the criteria based on the number of users and the overall revenue are determined in a flexible way. However, if the main aim for setting each threshold is to ensure significant economic activity and that compliance cost would be covered by the corresponding profits, it is more natural to apply absolute thresholds. (Brauner und Pistone, p. 38.)The starting point for setting the revenue threshold are the estimated costs for operating an additional permanent establishment.

If compliance costs are indeed proportional to turnover, then even with a profitability of only $1 \%$, (which is well below of what we typically see for digital companies), compliance costs should be safely covered. However, it is likely that there are substantial fixed compliance costs (that arise from the start and independent from the amount of turnover).

There is a high variability in the type and value of the contracts, depending on the business model. 
Moreover, also the acceptance of 'terms of service' for the use of an online platform could be assimilated to the conclusion of a contract. (OECD 2015a, p.110). If so, a high threshold, very similar to the one of the user would be needed. In any case, anybody who agrees to the 'terms of service' would also be counted as a user. If relevant for the business, the acceptance of 'terms of service' could be accepted as a way to measure number of users for a digital service rather than a threshold per se. An alternative threshold on the contracts concluded locally could have an added value if it is about business-to-business contracts. For example, a cloud-computing service might have relatively few 'users' if it offers its services primarily to businesses customers, but each contract concluded with such a business customer would typically generate more revenue than revenue generated form a single user that is a natural person. Therefore, a threshold on business-to-business contracts should be considerably lower than a user-based threshold.

\section{Research on the impact of the introduction of digital taxation in individual countries of the European Union}

The implementation of national digital taxes is likely to be accompanied by numerous undesirable side-effects. [4] Therefore, it is important to determine which policy tools might better level the playing field and ensure a fair share of the tax revenues from digital businesses.

Table 2 List of European Union countries that have introduced digital taxation (author research)

\begin{tabular}{|c|c|c|c|c|}
\hline Country & $\begin{array}{c}\text { Domestic Revenue } \\
\text { Threshold }\end{array}$ & Tax Rate & Scope & Status and essential features \\
\hline AT & $€ 25$ million & $5 \%$ & $\begin{array}{l}\text { Online advertising } \\
\text { services }\end{array}$ & $\begin{array}{l}\text { - Effective January 1, 2020; } \\
\text { ("Digitalsteuergesetz 2020") is based on } \\
\text { the European Commission's proposal on } \\
\text { the digital services tax from March } \\
2019 ; \\
\text { - Online advertising services provided by } \\
\text { online advertisers in Austria in } \\
\text { exchange for payment are taxable } \\
\text { (starting from } 1 \text { January 2020) (The law } \\
\text { is limited to online advertising services } \\
\text { provided within Austria, and online } \\
\text { advertising services are considered to be } \\
\text { provided within Austria if was received } \\
\text { on the device of a user with an Austrian } \\
\text { IP address, and in terms of content and } \\
\text { design (also) is directed towards } \\
\text { Austrian users); } \\
\text { Online advertising services are } \\
\text { considered to be ads placed on the } \\
\text { digital interface, in particular in the } \\
\text { form of advertising on signs, advertising } \\
\text { on search engines and similar } \\
\text { advertising services; taxpayers are } \\
\text { companies that provide or contribute to } \\
\text { online advertising services, which } \\
\text { within one financial year have a } \\
\text { worldwide turnover of at least } 750 \\
\text { million euros, while in the country they } \\
\text { have a turnover of at least } 25 \text { million }\end{array}$ \\
\hline
\end{tabular}




\begin{tabular}{|c|c|c|c|c|}
\hline Country & $\begin{array}{c}\text { Domestic Revenue } \\
\text { Threshold }\end{array}$ & Tax Rate & Scope & Status and essential features \\
\hline & & & & $\begin{array}{l}\text { euros from fees earned by providing } \\
\text { online advertising services; } \\
\text { The tax base for digital tax assessment } \\
\text { is the fee that the online advertising } \\
\text { service provider receives from the } \\
\text { customer. }\end{array}$ \\
\hline $\mathrm{BE}$ & $€ 50$ million in the $\mathrm{EU}$ & $3 \%$ & Sales of user data & $\begin{array}{l}\text { - Proposed } \rightarrow \text { has not yet entered into } \\
\text { force, nor is there any indication of } \\
\text { when it could; on } 23 \text { January } 2019 \text {, a } \\
\text { bill was submitted to the House of } \\
\text { Representatives seeking to introduce a } \\
\text { temporary tax at Belgian level on the } \\
\text { most important digital services of the } \\
\text { "internet giants" who are currently } \\
\text { evading taxes in the EU; } \\
\text { - The proposal mainly targets internet } \\
\text { giants. The tax is targeted at companies } \\
\text { with a total global revenue of more than } \\
€ 750 \text { million and a total taxable income } \\
\text { in the EU of at least } € 50 \text { million. The } \\
\text { company is responsible for DST in } \\
\text { Belgium when the customer is in } \\
\text { Belgium at the time of providing the } \\
\text { taxable service (localization based on IP } \\
\text { address). }\end{array}$ \\
\hline $\mathrm{CZ}$ & $\begin{array}{l}\text { CZK } 100 \text { million } \\
\text { (aprox. } € 4 \text { million) }\end{array}$ & $7 \%$ & $\begin{array}{l}\text { 1. Targeted advertising } \\
\text { via digital interface; } \\
\text { 2. Use of a multilateral } \\
\text { digital interface; and } \\
\text { 3. Sales of user data }\end{array}$ & $\begin{array}{l}\text { - CZ Government approved the proposal, } \\
\text { it still needs to be approved by the } \\
\text { Parliament } \rightarrow \text { it is expected to enter into } \\
\text { force in mid-2020; } \\
\text { - The draft law specifies a minimum } \\
\text { threshold for the taxation of certain } \\
\text { digital services. For the provision of } \\
\text { targeted advertising services and the } \\
\text { sale of user data, the amount of payment } \\
\text { for a particular service provided in the } \\
\text { Czech Republic should exceed CZK } 5 \\
\text { million. Use of multilateral digital } \\
\text { interfaces is subject to digital services } \\
\text { tax if the number of user accounts on the } \\
\text { interface exceeds 200,000; } \\
\text { The tax would apply to companies with } \\
\text { a global turnover of more than EUR 750 } \\
\text { million and a tax base relating to taxable } \\
\text { digital services provided in the Czech } \\
\text { Republic of over CZK } 100 \text { million }\end{array}$ \\
\hline
\end{tabular}




\begin{tabular}{|c|c|c|c|c|}
\hline Country & $\begin{array}{c}\text { Domestic Revenue } \\
\text { Threshold }\end{array}$ & Tax Rate & Scope & Status and essential features \\
\hline & & & & (approximately EUR 4 million). \\
\hline FR & $€ 25$ million & $3 \%$ & $\begin{array}{l}\text { 1. Making the "digital } \\
\text { interface" available; } \\
\text { and } \\
\text { 2. } \\
\text { Advertising Service }\end{array}$ & $\begin{array}{l}\text { Retroactively entered into force on } 1 \\
\text { January 2019, however its } \\
\text { implementation has been temporarily } \\
\text { postponed until the end of } 2020 \text { due to } \\
\text { US threats to impose high tariffs on } \\
\text { French products; the French DST } \\
\text { recognizes two categories of taxable } \\
\text { digital services: 1. a "digital interface" } \\
\text { service and 2. a "targeted advertising" } \\
\text { service. } \\
\text { The law defines the provision of a } \\
\text { "digital interface" as providing, by } \\
\text { electronic communications, a digital } \\
\text { interface that allows users to contact and } \\
\text { interact with other users, especially for } \\
\text { the purpose of delivering goods or } \\
\text { providing services directly between } \\
\text { those users, while defining a "targeted } \\
\text { advertising" service as services } \\
\text { marketed to advertisers or their agents } \\
\text { for the purpose of placing on a digital } \\
\text { advertising interface targeted based on } \\
\text { user data collected or generated when } \\
\text { such sites are visited. These services } \\
\text { may include, in particular, the purchase, } \\
\text { storage and placement } \\
\text { advertisements, advertising and } \\
\text { performance monitoring, and user data } \\
\text { management and transmission services; }\end{array}$ \\
\hline
\end{tabular}




\begin{tabular}{|c|c|c|c|c|}
\hline Country & $\begin{array}{c}\text { Domestic Revenue } \\
\text { Threshold }\end{array}$ & Tax Rate & Scope & Status and essential features \\
\hline & & & & $\begin{array}{l}\text { - Taxpayers are digital companies with } \\
\text { global gross revenues from digital } \\
\text { services of at least } € 750 \text { million and of } \\
\text { at least } € 25 \text { million in France. }\end{array}$ \\
\hline $\mathrm{HU}$ & N/A & $7.5 \%$ & Advertising & $\begin{array}{l}\text { - In 2014, Hungary introduced an } \\
\text { advertising tax, which is a special sales } \\
\text { tax applicable to the broadcasting or } \\
\text { publication of advertisements in } \\
\text { Hungary; } \\
\text { - Business entities that broadcast or } \\
\text { publish advertisements are subject to } \\
\text { this tax, ie, in particular, newspapers, } \\
\text { audiovisual media and billboards; } \\
\text { - The taxable amount of tax is the net } \\
\text { turnover in the financial year generated } \\
\text { by the broadcasting or publication of } \\
\text { advertisements, to which progressive } \\
\text { rates ranging from 0\% to } 50 \% \text { are } \\
\text { applied; } \\
\text { Subsequently, Hungary replaced the six } \\
\text { progressive rates scale with a scale } \\
\text { containing two rates: a } 0 \% \text { rate for the } \\
\text { part of the taxable amount below HUF } \\
100 \text { million (approximately EUR } \\
300,000) \text { and a second rate, } 5.3 \% \text {, for } \\
\text { the part of the taxable amount above } \\
\text { that amount; } \\
\text { In 2017, Hungary amended its } \\
\text { advertising tax again to comply with EU } \\
\text { rules, raising the upper threshold of the } \\
\text { progressive tax rate to } 7.5 \% \text { for } \\
\text { taxpayers with sales revenues over HUF } \\
100 \text { million. }\end{array}$ \\
\hline
\end{tabular}




\begin{tabular}{|c|c|c|c|c|}
\hline Country & $\begin{array}{c}\text { Domestic Revenue } \\
\text { Threshold }\end{array}$ & Tax Rate & Scope & Status and essential features \\
\hline IT & $€ 5.5$ million & $3 \%$ & $\begin{array}{l}\text { 1. Placing on the } \\
\text { digital interface } \\
\text { advertising targeted at } \\
\text { users of that interface; } \\
\\
\text { 2. Making the } \\
\text { multilateral digital } \\
\text { interface available to } \\
\text { users, enabling users to } \\
\text { find and interact with } \\
\text { other users, which may } \\
\text { also facilitate the } \\
\text { provision of goods or } \\
\text { services directly } \\
\text { between users; and } \\
\text { 3. Sale of collected } \\
\text { user data generated } \\
\text { from user activities on } \\
\text { the digital interface } \\
\text { and }\end{array}$ & $\begin{array}{l}\text { Effective January 1,2020; } \\
\text { On December 27, 2019, the Italian } \\
\text { Parliament approved the Budget Law } \\
\text { for } 2020 \text {. (Italian Budget Law 2020; } \\
\text { Law No. } 160 \text { of } 2019 \text { published in the } \\
\text { Italian Official Gazette on December } 30, \\
2019 \text { ), which, among other things, } \\
\text { presents a new tax on digital services, } \\
\text { which has been applied since January } 1 \text {, } \\
\text { 2020. Mr. } \rightarrow \text { is mostly based on the } \\
\text { European Commission's proposal on the } \\
\text { digital services tax from } 2018 \text {; taxable is } \\
\text { the revenue collected during the year } \\
\text { from the provision of digital services to } \\
\text { users within Italy, which as such are } \\
\text { identified by the IP address of the } \\
\text { devices they use or by applying the } \\
\text { geolocation method; } \\
\text { Taxpayers are companies that } \\
\text { individually or as part of a group in the } \\
\text { year before the relevant calendar year } \\
\text { generate a total revenue of at least EUR } \\
750 \text { million, and in Italy a turnover of at } \\
\text { least EUR } 5.5 \text { million; } \\
\text { Italian DST will be automatically } \\
\text { abolished in case a global solution is } \\
\text { adopted. }\end{array}$ \\
\hline $\mathrm{ES}$ & $€ 3$ million & $3 \%$ & $\begin{array}{l}\text { 2. Making the } \\
\text { multilateral digital } \\
\text { interface available to } \\
\text { users, enabling users to } \\
\text { find and interact with } \\
\text { other users, which may } \\
\text { also facilitate the } \\
\text { provision of goods or } \\
\text { services directly } \\
\text { between users; and }\end{array}$ & $\begin{array}{l}\text { Proposed } \rightarrow \text { has not yet entered into } \\
\text { force, nor is there any indication of } \\
\text { when it could; } \\
\text { The Spanish Parliament rejected the } \\
\text { Government's proposal of } 19 \text { January } \\
\text { 2019. proposing the introduction of } \\
\text { DST; it is expected that the new } \\
\text { Government could re-propose the } \\
\text { introduction of DST; only the provision } \\
\text { of digital services used by persons } \\
\text { located in Spain will be taxed by the } \\
\text { Spanish digital tax (digital services are } \\
\text { considered to be performed within } \\
\text { Spanish territory whenever the user is in } \\
\text { Spain; special localization rules are set } \\
\text { for each type of taxable digital service) } \\
\text { Taxpayers are legal entities, regardless }\end{array}$ \\
\hline
\end{tabular}




\begin{tabular}{|c|c|c|c|c|}
\hline Country & $\begin{array}{c}\text { Domestic Revenue } \\
\text { Threshold }\end{array}$ & Tax Rate & Scope & Status and essential features \\
\hline & & & $\begin{array}{l}\text { 3. sale of collected user } \\
\text { data generated from } \\
\text { user activities on the } \\
\text { digital interface }\end{array}$ & $\begin{array}{l}\text { of their residency, that in a calendar year } \\
\text { generate total global revenue of at least } \\
\text { EUR } 750 \text { million and more than EUR } 3 \\
\text { million of revenue generated in Spain. }\end{array}$ \\
\hline UK & $\begin{array}{l}£ 25 \text { million } \\
\text { (€28 million) }\end{array}$ & $2 \%$ & $\begin{array}{l}\text { Revenues from social } \\
\text { media } \\
\text { search engines and } \\
\text { online marketplaces }\end{array}$ & $\begin{array}{l}\text { Proposed } \rightarrow \text { expected to enter into force } \\
\text { in April } 2020 \text {; the tax will be applied to } \\
\text { revenues from social media platforms, } \\
\text { search engines and online markets } \\
\text { (financial and payment services are } \\
\text { excluded); } \\
\text { Taxpayers are companies that generate } \\
\text { global annual digital revenues of } £ 500 \\
\text { million and } £ 25 \text { million in the UK; } \\
\text { The first } £ 25 \text { million of user revenue in } \\
\text { the UK will not be subject to DST. }\end{array}$ \\
\hline
\end{tabular}

In Table 2 the author explores the thresholds and targets of taxation in countries that have implemented the digital tax. European Union countries have moved forward with the introduction or proposal of unilateral measures. This legislation has primarily served two aims, namely allocating an appropriate share of the tax revenues from digital services to the particular country and reducing tax inequality between domestic and digital business models. The national digital taxes implemented and proposed in the European Union territory can be allocated to three groups, including the tax type, the tax scope and the tax base.

\section{Conclusion}

Until the implementation of a common and coordinated action at EU level, which may take some time to agree, Member States introduce unilateral measures to address the challenges of taxing the digital economy companies. EU action is necessary in order to mitigate the fragmentation of the single market and the creation of distortions of competition within the EU due to the adoption of such unilateral actions at national level.

The preferred option would be consistent with the principle of proportionality. As follows from the subsidiarity test, it is not possible for Member States to address the problem without hampering the single market. Moreover, the present proposal aims at setting a common structure of the tax, narrowly defined with thresholds not to unjustifiably hurt companies, while leaving sufficient margin of manoeuvre for Member States when it comes to actual setting of certain administrative aspects related to the measure, such as accounting and reporting obligations, and also concerning the prevention of evasion, avoidance, and abuse.

\section{References:}

[1] Becker, J., Englisch, J. (2018). EU Digital Services Tax: A Populist and Flawed Proposal. Kluwer International Tax Blog. Retrieved 26.11.2020. from https://www.kluwertaxblog.com

[2] Brauner und Pistone (2017), 'Adapting Current International Taxation to New Business Models: Two Proposals for the European Union', Bulletin for International Taxation, Vol. 71, No. 12.

[3] IAB Europe and IHS Markit (2017), 'The economic contribution of digital advertising in Europe', $\quad$ Retrieved 19.09.2019 from $\mathrm{http}: / /$ iabsverige.se/project/the-economiccontribution-of-digital-advertising-in-europe/

[4] Kofler, G., Mayr, G., \& Schlager, C. (2017). Taxation of the Digital Economy: "Quick Fixes" or Long-Term Solution?, European Taxation, $57 . \quad$ Retrieved from 
https://research.ibfd.org/\#/doc?url=/collections/ et/html/et_2017_12_e2_1.html.

[5] OECD (2015a), 'Addressing the Tax Challenges of the Digital Economy: Action 1 2015 Final Report', Organisation for Economic Co-operation and Development (OECD), Paris.

[6] Schön, W. (2018) Ten Questions About Why and How to Tax the Digitalized Economy, Bulletin for International Taxation, 72. Retrieved 26.11.2020. from https://research.ibfd.org/\#/doc?url=/collections/ bit/html/bit_2018_04_int_1.html

[7] UNCTAD (2017a), 'World Investment Report 2017: Investment and the Digital Economy', United Nations, New York and Geneva, Retrieved 20.11.2020. from https://www.statista.com/download/outlook/wh iterpaper/Fullpage/2/219/102/2_219_102.pdf)

[8] UNCTAD (2017b), 'The Top 100 Digital MNEs', Technical annex to the World Investment Report 2017, United Nations, New York and Geneva, Retrieved 20.11.2020. from https://www.statista.com/download/outlook/wh iterpaper/Fullpage/2/219/102/2_219_102.pdf)

[9] UNCTAD (2017c), 'Information Economy Report 2017: Digitalization, Trade and Development', United Nations, New York and Geneva, Retrieved 20.11.2020. from https://www.statista.com/download/outlook/wh iterpaper/Fullpage/2/219/102/2_219_102.pdf)

[10] UNCTAD and OECD Digital Economy Outlook, (2017) Projections for these developments can be found inter alia in the Statista Digital Market Outlook, (2017a,2017b), Retrieved 20.11.2020. from https://www.statista.com/download/outlook/wh iterpaper/Fullpage/2/219/102/2_219_102.pdf)

[11] VAT Implementing Regulation, Article 7 'Electronically supplied services' include services which are delivered over the Internet or an electronic network and the nature of which renders their supply essentially automated and involving minimal human intervention, and impossible to ensure in the absence of information technology

\section{Contribution of individual authors to the creation of a scientific article}

Mario Hak- writing - original draft, investigation, editing and supervision.

Anton Devčić- writing - methodology, review, editing, investigation, and data analysis.

Hrvoje Budić- methodology, review, and editing.

\section{Sources of funding for research presented in a scientific article or scientific article itself}

Not applicable

\section{Creative Commons Attribution}

\section{License 4.0 (Attribution 4.0 \\ International , CC BY 4.0)}

This article is published under the terms of the Creative Commons Attribution License 4.0

https://creativecommons.org/licenses/by/4.0/deed.en US 